\title{
Deformation In Northern Vietnam under The Influence of SE Asian Tectonics and Its Impact to Natural Resources Accommodation
}

\author{
Bui Thi Thanh Huyen ${ }^{\text {1) }}$ Yasuhiro Yamada ${ }^{\text {l) }}$ Toshifumi Matsuoka ${ }^{1)}$ \\ 1) Dept. of Earth Resources Engineering, Kyoto University, Kyoto, 606-8501, Japan.
}

\begin{abstract}
Geological structures of Vietnam, locating at the eastern margin of SE Asia, experienced numerous tectonic phases during Cenozoic Era that is especially marked by the collision of India-Eurasia. This collision caused strike-slip movements along the Red River Fault (RRF) and opening the South China Sea (SC Sea). The movements of the RRF affected structural styles in onshore and offshore northern Vietnam territory and the deformation history is recorded in the sediments of the Red River basin (RR basin). In this paper, the authors present some maiden results from seismic interpretation in the northern Vietnam for illustrating deformation of geological sequences under regional tectonics and how this deformation acts upon the oil and natural gas generating, migrating and accumulating, which are still remaining as hot topics for petroleum industry.
\end{abstract}

\section{Introduction}

This paper firstly reviews the regional tectonics and petroleum geology that are vital information for this study, then briefly introduce our data and some preliminary results from our interpretations.

\section{Regional Tectonic Framework}

Cenozoic Era is marked by some magnificent tectonic events and the collision between India and Eurasia is the most spectacular one among them. Indian plate started to drift to the north since $70 \mathrm{Ma}$ (Dewey et al, 1989) and the collision firstly occurred at oceanic arcs. The true collision of continental plates commenced at 45-50 Ma (Tapponier et al, 1986; Le Pichon, 1992) and created deformation zone at Tibet and Himalaya. Figure 1 shows the schematic motion of Indian plate relative to Eurasia.

Figure 2 illustrates how the collision of India-Eurasia affects the present-day tectonics of SE Asia. The Indian subcontinent indented into Eurasia and the crustal Tibet was fragmented and extruded to the southeast that caused Indochina block counter clock-wise rotation. The Red River Fault (RRF), that is a border of the South China block and the Indochina block is an evidence of the deformation zone of the India-Eurasia collision that extended to the southeast to the offshore Gulf of Tonkin, where onset of sinistral displacement causal approximately $32 \mathrm{Ma}$. This may be the main reason to generate the opening of the South China Sea (SC Sea) at $32 \mathrm{Ma}$ (Taylor \& Hayer, 1980, 1983).

The left lateral displacement along the RRF ceased at $17 \mathrm{Ma}$, and the spreading in the South 
China Sea ended at 15.5 Ma. The directions of the SC Sea spreading are roughly in the N-S and NW-SE in the southwest of the basin. Simplified structural styles of the RRF displacements and the SC Sea spreading are expressed in Figure 3. The subduction beneath the Manila Trench of the South China Sea since Late Miocene might change the Red River Fault to the dextral displacement.

\section{Outline of Red River (Song Hong) Basin Evolution}

The Red River Fault extends to the Gulf of Tonkin, offshore northern Vietnam with two northeastern branch systems, Song Chay and Song Lo, forming the margins of the Red River basin (Song Hong basin in Vietnamese).

The Song Hong basin, the largest basin in Vietnam, consists of onshore Hanoi Trough and its offshore extension can be classified as a typical pull-apart basin filled with more than $15000 \mathrm{~m}$ of Tertiary sediments at its depocentre. Most depositions are clastics with the existence of carbonates in Miocene time at the southern part of the Song Hong basin and some volcanics are found in Pliocene- Pleistocene strata. Tectonic evolution of the Song Hong basin is in accordance with the Red River Fault system development and its rhomboidal shape is restrained by strike-slip displacements of the fault system underwent many tectonic phases since its generation (32 Ma). Primarily structural elements of Song Hong basin are expressed in Figure 4 and they can be summarized as:

- Early rifting period: The rifting occurred during Eocene-Oligocene with high rate of sedimentation in grabens. During this stage, most of the area was exposed to sub-aerial erosion and only some grabens were filled by fluvial and lacustrine sediments. Coarse clastics deposited near the flanks and fine sediments are in the center of the basin.

- Late Rifting period: During Early and Middle Miocene continuous subsidence and wide opening of the grabens and half grabens consisting mainly sandstones and claystones.

- Post Rift period: This period was characterized by downlap features on the seismic sections, that might be onset during Middle and Late Miocene with transpressional plays and tectonic inversion where reverse movements occurred. Some mud diapirs were also observed on the seismic profiles.

Based on the distribution and lithology of the sediments, the basin can be divided into three main regions: the Hanoi Trough, offshore North and offshore South. The stratigraphy of Song Hong basin is consisted of Pre-Tertiary basement, Eocene (?)- Oligocene, Lower Miocene, Middle Miocene, Late Miocene, Pliocene and Quaternary. Figure 5 describes an overview of general stratigraphy and petroleum system of the basin.

\section{Petroleum Geology}

Since the end of 1950s geophysical and geological activities have been carried out in the northern part of Vietnam territory including the Song Hong basin. The first well was drilled in Hanoi basin in 1969 and Tien Hai gas field was discovered in 1975. Up to present, more than 
$60,000 \mathrm{~km}$ of seismic profiles were acquired and about $40^{\circ}$ wells were drilled in the basin, resulting in 12 oil and gas shows, with two gas fields are put in production. Potential reservoirs are Pre-Tertiary fractured granite basement and Oligocene-Miocene sandstones in the north, Oligocene-Miocene sandstones and- Middle Miocene carbonate plays in the south. Source rocks are Oligocene lacustrine oil prone shales and Oligocene-Miocene deltaic/paralic gas-prone coal/coaly shales. Regional seals are Oligocene delta plain or prodelta lacustrine shales and Miocene transgressive shales.

Due to recent studies, the Song Hong basin is considered as a gas prone basin and may contain 2.5 billion barrels of oil equivalent (predominantly gas), accounting for approximately $15 \%$ of the total hydrocarbon resources of Vietnam. Although hydrocarbon shows have been encountered in many wells of the Song Hong basin, no large gas field has been found. A better understanding of its complexity in the structural deformation along the active strike-slip Red River Fault system is very important and necessary.

\section{The Data and Preliminary Results of Our Seismic Interpretation:}

In this research, we used seismic profiles to cover most area of the Song Hong basin and some offshore wells to execute structural interpretation and to compare with the previous works. Among them, we show for seismic profiles in this paper on the Figure 6.

On the line 2 (Figure 7) major fault systems and synrift sediments aged Oligocene and Early Miocene can be seen. The rate of deposition is high at the center of the basin structure and the thickness of the sediments significantly decreased to the bounding faults because of fault re-activations. Basement rose up at flanks of the basin that are controlled by the main fault systems. At some basement highs, Oligocene or Early Miocene sediments were eroded with truncated or top-lap features on the seismic sections.

On the line 3 (Figure 8), a flower- structures can be clearly observed that deformed Miocene sediments (particularly Middle Miocene). The thickened layers were strongly folded and sagged. After rifting phase, basin that locally uplifted can be interpreted from seismic sections even inside synrift structural center (from restored cross section for line 4 in Figure 9). In this figure, the authors restored a simplified deposition evolution in the basin for some particular geological stages such as Oligocene-Early Miocene, Middle Miocene and present-day. From this section, we can recognize that, tectonics of the Song Hong basin underwent very complicated geological processes that demand to be more detail studied.

In Figure 10, that is sub-parallel to the elongated axis of the basin, we can see clearly inclination of sediments to the basin center.

As the Song Hong basin is one of the most typical strike-slip basins, the geometry and dynamic mechanism of the fault systems are difficult to be understood. Seismic imaging of strike-slip structures is generally poor because of the steep strata and fault dips or complicated deformation of the sediments. Our interpretation of fault geometry shows, however, similar to those of the experiments by McClay and Bonora for a restraining strike-slip fault system (Figure 11 and 12). 
Branch-fault systems in the Figure 11 are commonly found in the most seismic profiles in the Song Hong basin with much more complicated forms. The flower structure on the seismic profile 3 may have an extremely similar shape with experimental result (Figure 12) if having enough data to create 3-D geometry.

\section{Future Works}

The generation and evolution processes of the Song Hong basin is still a markedly question. In addition, the reason why such a very strong gas prone basin has only a few minor prospects while containing very good source rocks, seals traps and suitable maturation. These will be explained more clearly as our research on the basin study progresses.

\section{Acknowledgements}

We would like to express our special thanks to RAEG Organization Committee for inviting us to attend this scientific event. Many thanks go to PetroVietnam for providing us the data to carry out this work.

\section{References}

Dewey, J.F et al., 1989: Tectonic evolution of the India/Eurasia Collision Zone. Eclogae geol. Helv. 82/3: 717-734.

Ken McClay and Bonora (2001) Analogue Models of Restraining Stepover in Strike-slip Fault System. AAPG Bulletin, v. 85, No. 2 (February 2001), p. 233-260.

Le Pichon X., Fournier M., \& Jolivet L. (1992) Kinematics, topography, shortening, and extrusion in the India-Eurasia collision. Tectonics 11 (6), 1085-1098.

Reports of Vietnam Petroleum Institute for Song Hong basin, 1992, 1999.

Tapponnier P., Peltzer G., Le Dain A.Y., Armijo R., \& Cobbold P. (1982) Propagating extrusion tectonics in Asia: New insights from simple experiments with plasticine. GEOLOGY 10,611-616.

Taylor, B. \& Hayer, D. E. 1980. The tectonic evolution of the South China Basin. In: HAYES, D. E. (ed.) The Tectonic and Geologic Evolution of South-east Asian Seas and Islands. American Geophysical Union Monograph, 23, 89-104.

Taylor, B. \& Hayer, D. E. 1983. Origin and history of the South China Basin. In: Hayer, D. E. (ed.) The Tectonic and Geologic Evolution of South-east Asian Seas and Islands, Part 2. American Geophysical Union Monograph, 27, 23-56. 


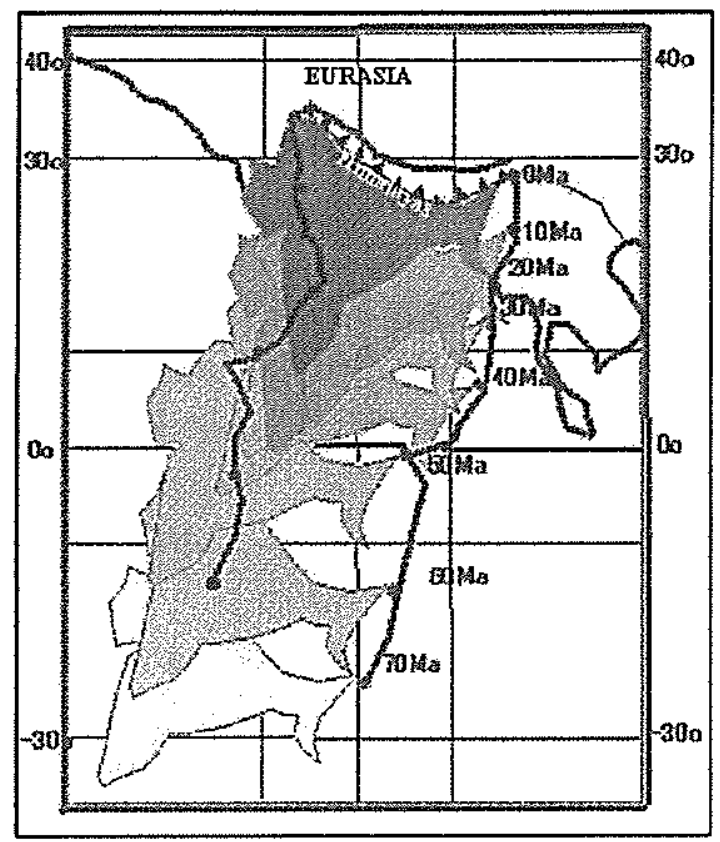

Figure 1. Kinematic motion of India relative to Eurasia

(modified from Le Pichon, Dewey and Tapponier)

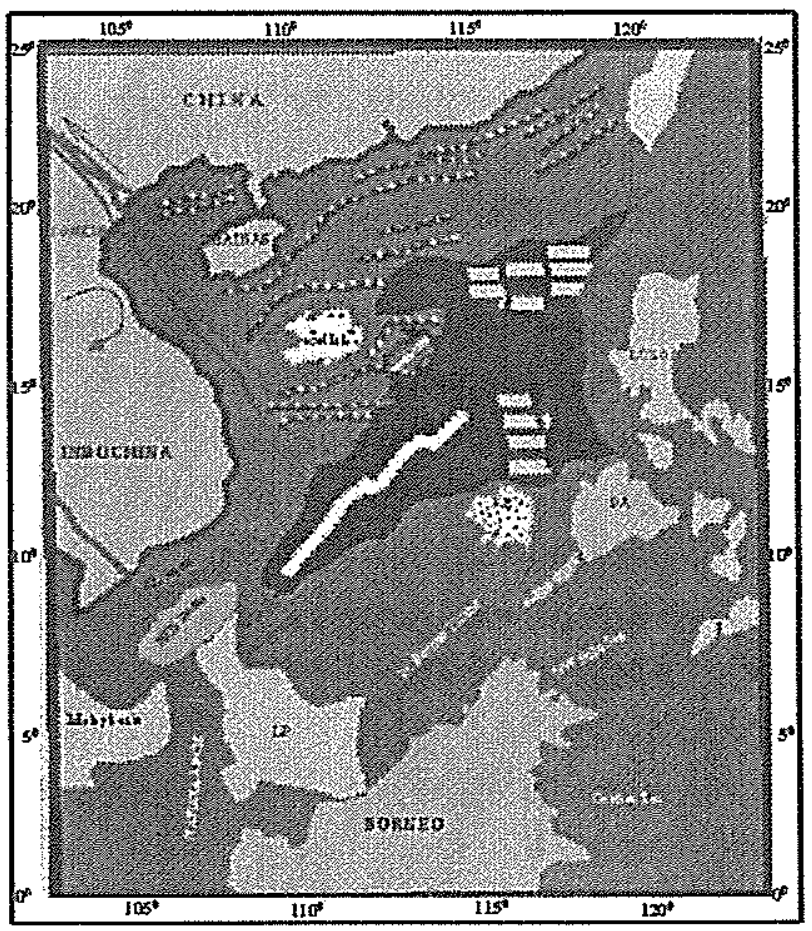

Figure 3. Simplified structural styles of the RRF and the SC Sea last $30 \mathrm{Ma}$ (modified from G. Packham, 1996)

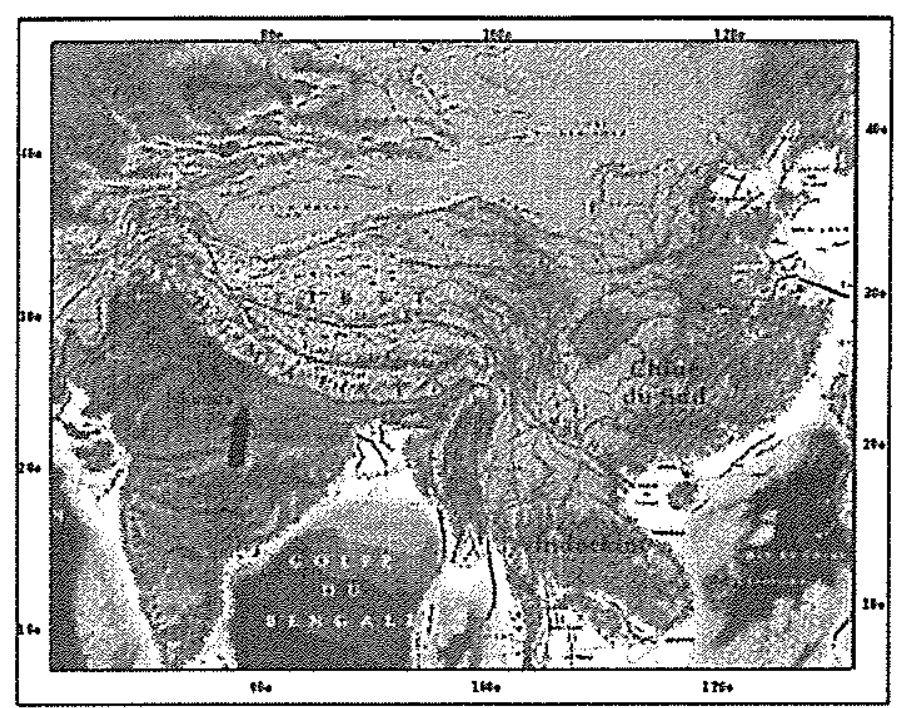

Figure 2. Map of the India-Eurasia convergence zone (from Métivier, 1996).

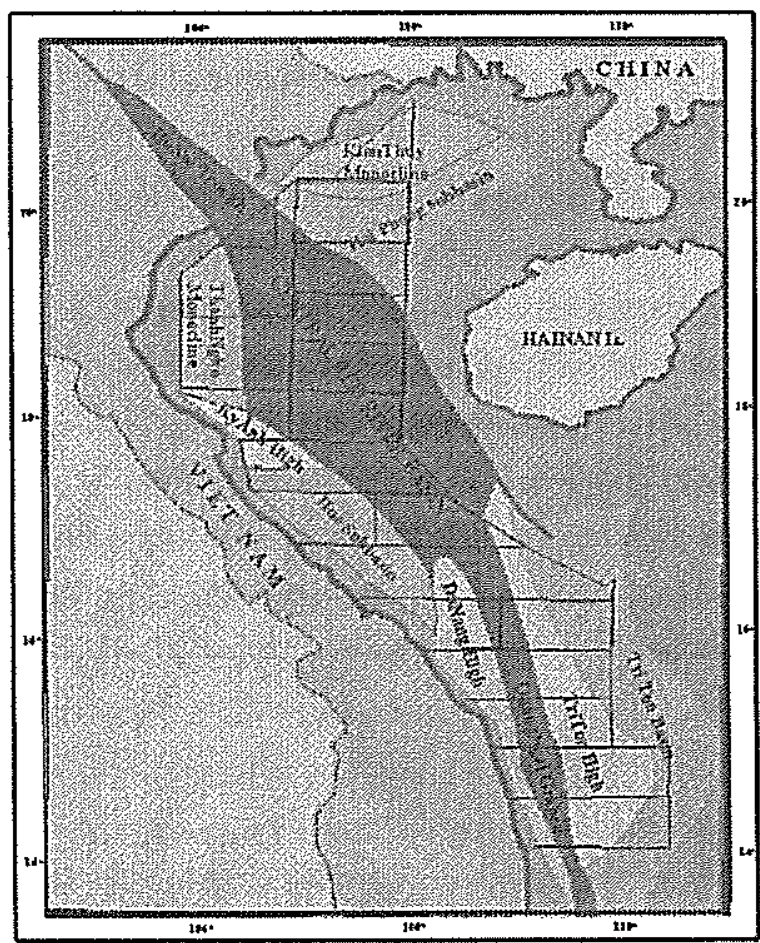

Figure 4. Structural elements of the Song Hong basin 


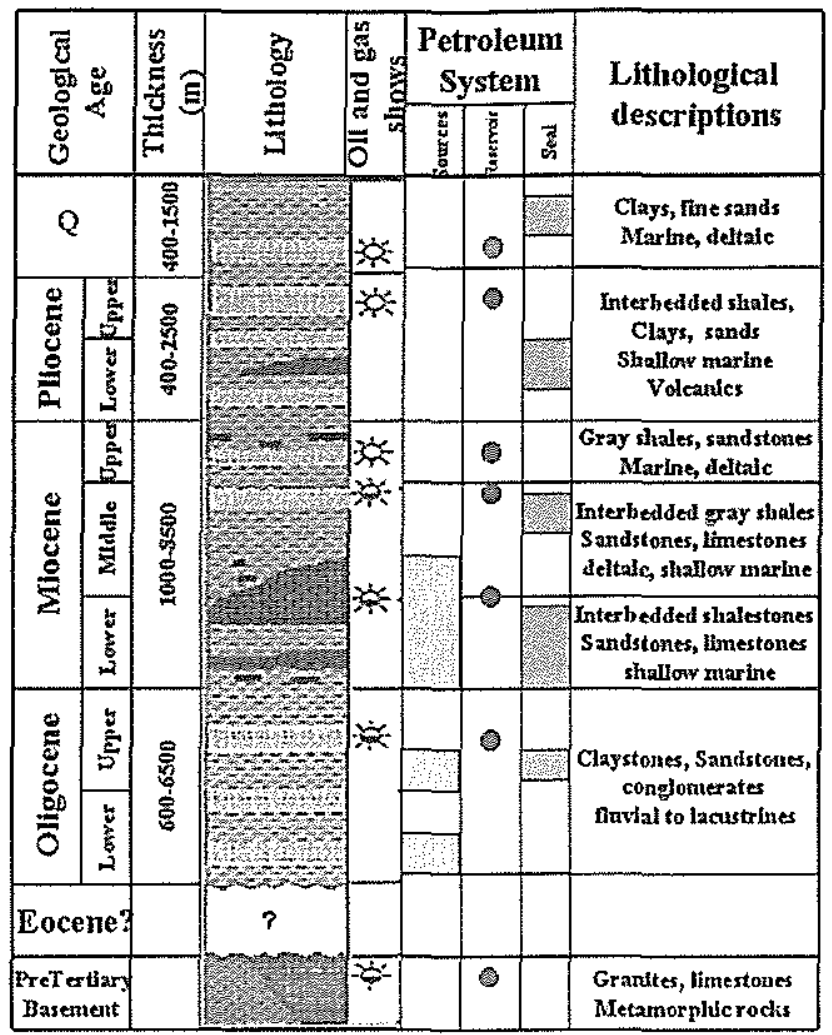

Figure 5. Stratigraphy in Song Hong basin

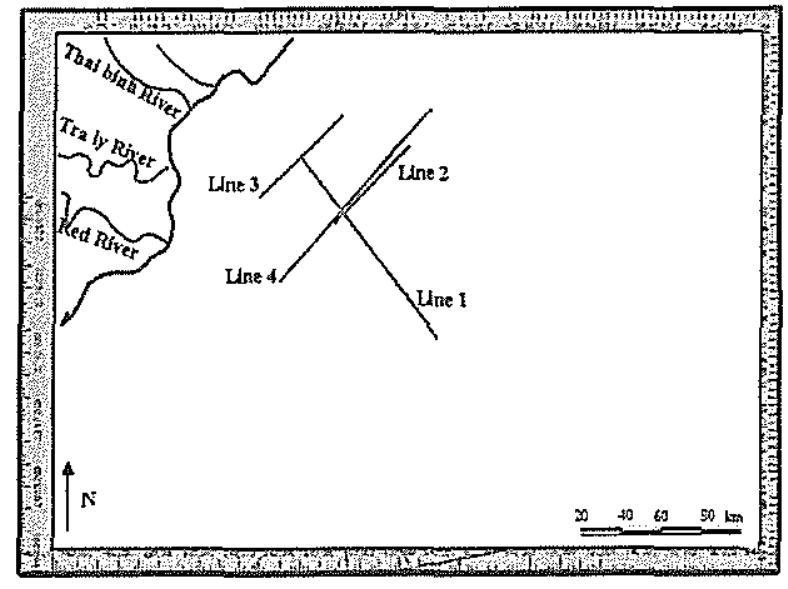

Figure 6. Location map of seismic profiles

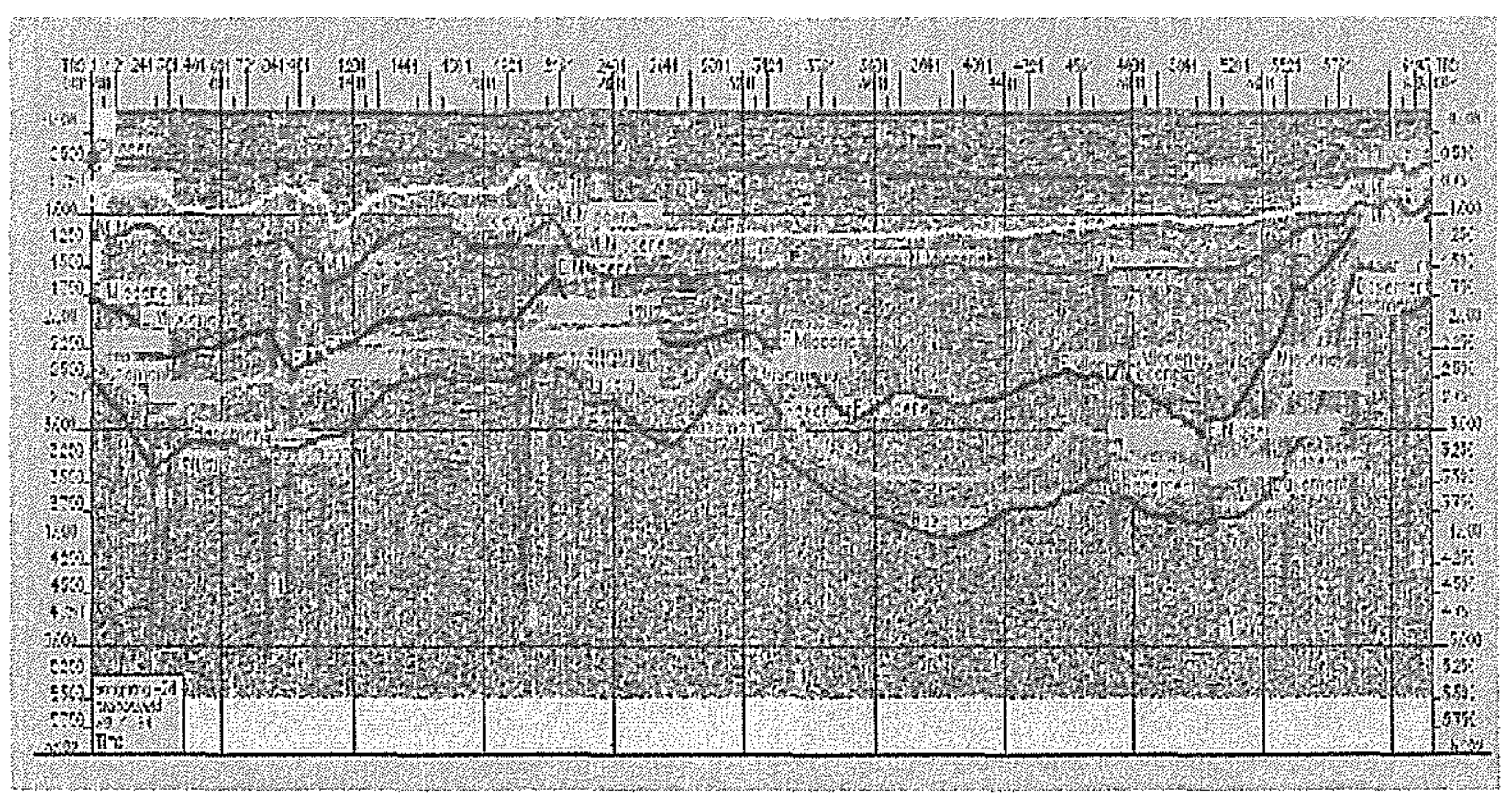

Figure 7.Seismic profile of line number 2 in Figure 6. The main fault system and synift sediments can be recognized. 


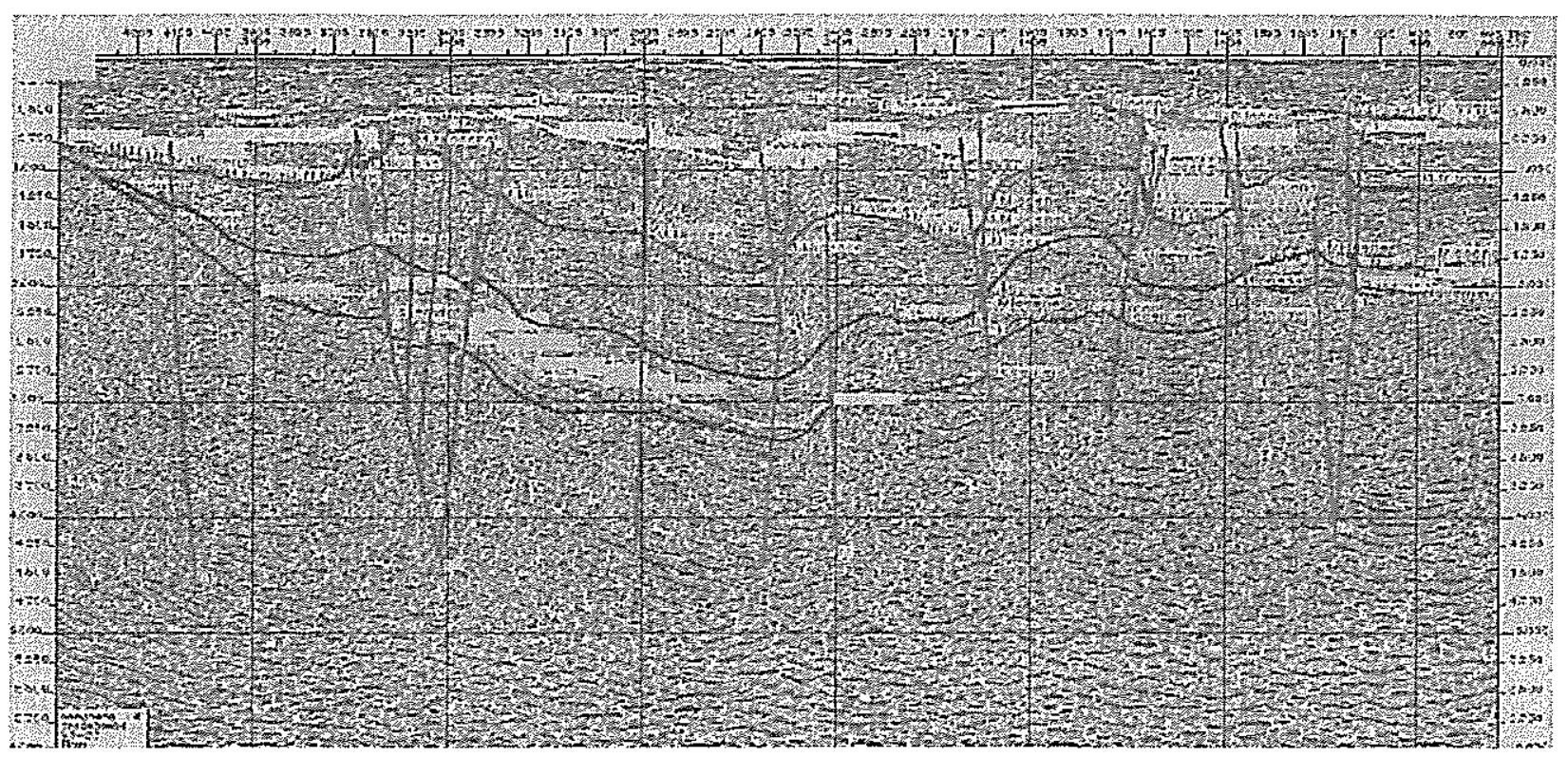

Figure 8. A seismic profile of line number 3 in Figure 6. Flower structure formed in the Miocene sediments reactivation of the master fault system

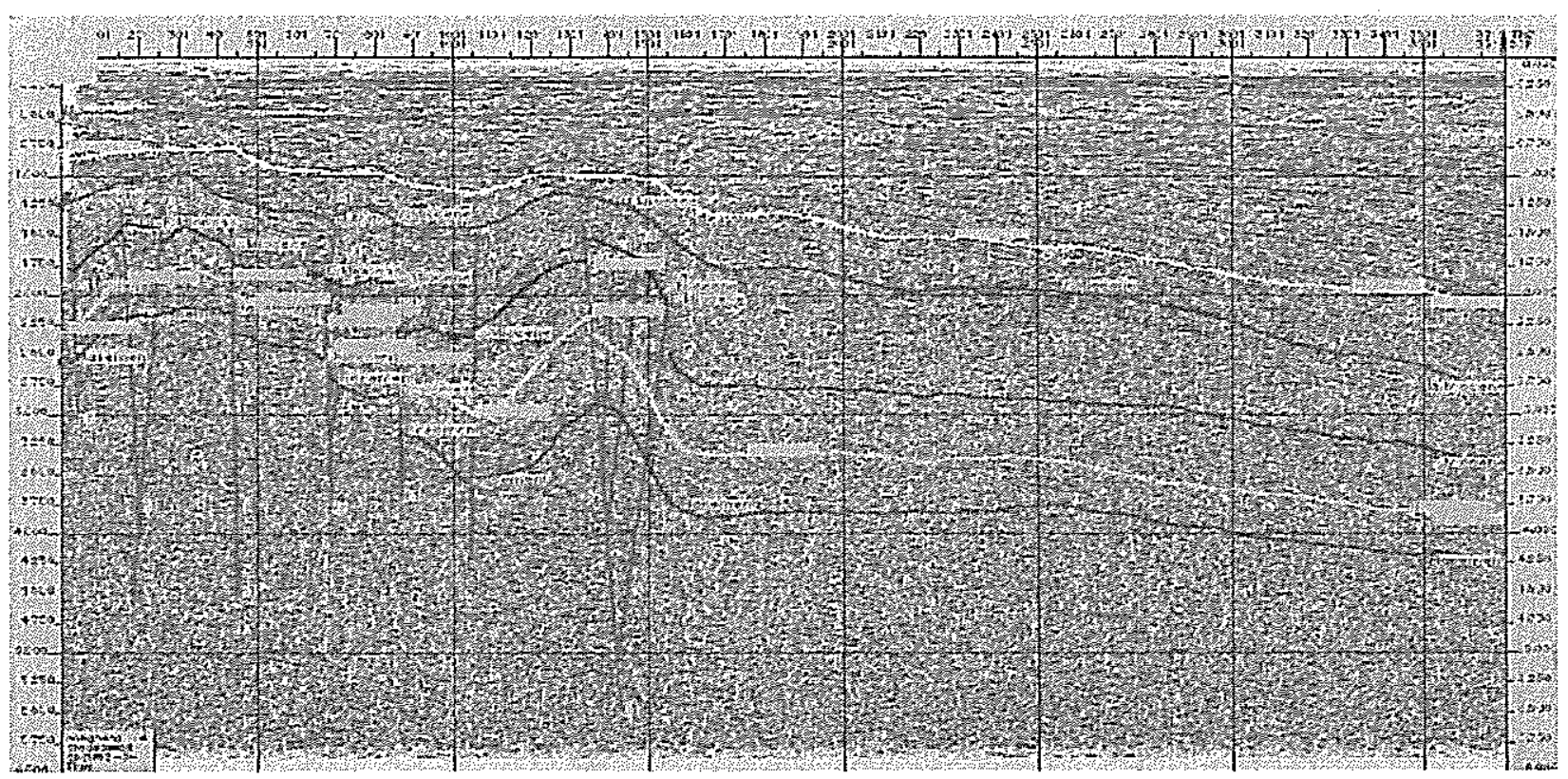

Figure 9. Seismic profile of line number 1 in Figure 6. Basement subsided at the basin center in the Song Hong basin 

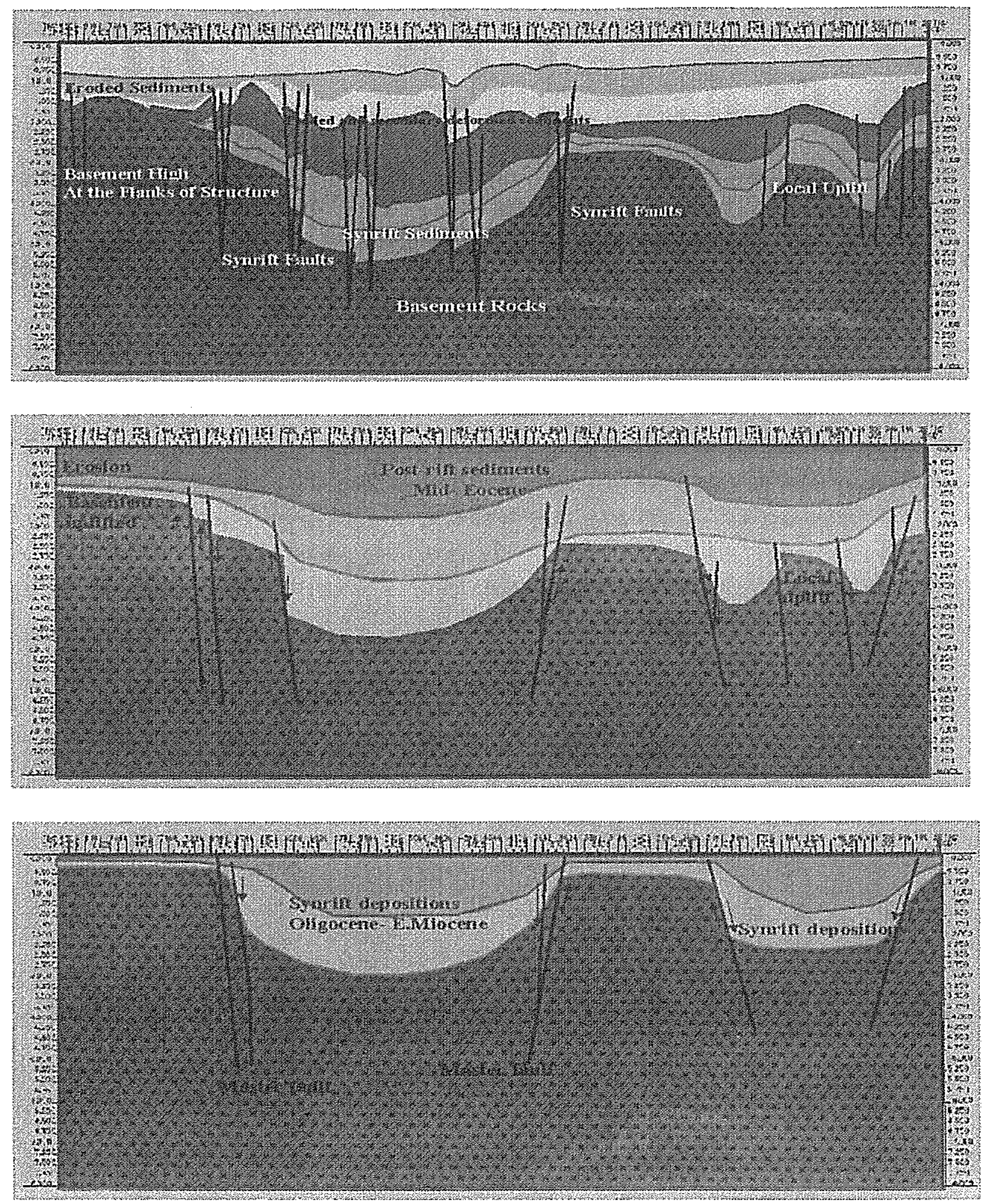

Figure 10. A seismic profile of line number 4 in Figure 6. Restored cross section for

a) Present-day; b) Mid-Miocene; c) Oligocene- Early Miocene (a, b, c counted from up to down) 

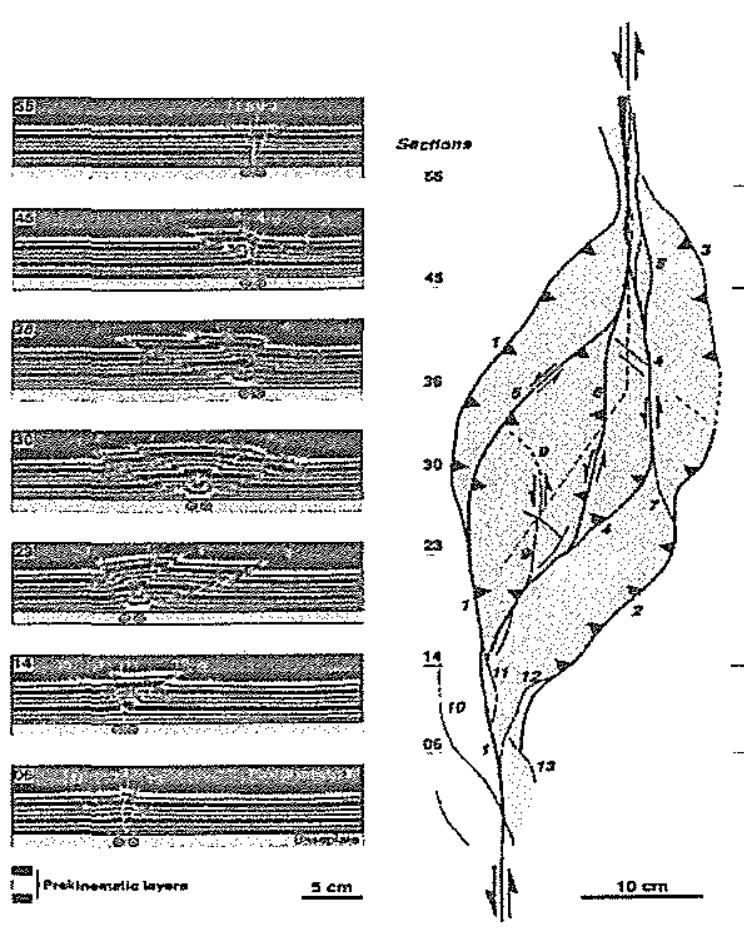

Figure 11. An analogue model of strike-slip fault systems (from K. McClay and M. Bonora, 2001)

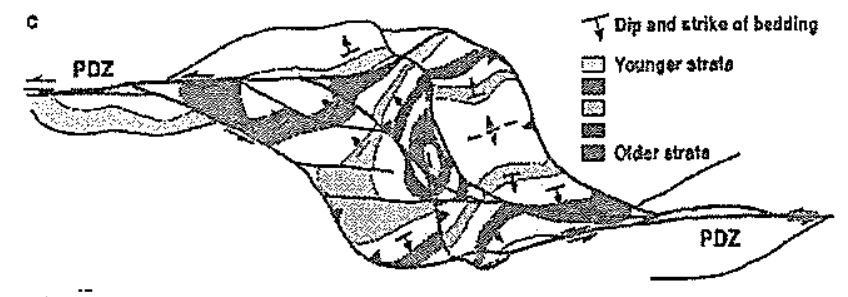

Figure 12. Structural map of an analogue strike-slip experiment (from K. McClay and M. Bonora, 2001) 